\title{
Factors controlling sediment trapping in two freshwater tidal wetlands in the Biesbosch area, The Netherlands
}

\author{
Eveline C. van der Deijl ${ }^{1}$ (D) - Marcel van der Perk ${ }^{1} \cdot$ Hans Middelkoop ${ }^{1}$
}

Received: 7 November 2016 / Accepted: 8 May 2017 / Published online: 1 June 2017

(C) The Author(s) 2017. This article is an open access publication

\begin{abstract}
Purpose A thorough understanding of mechanisms controlling sedimentation and erosion is vital for a proper assessment of the effectiveness of delta restoration. Only few field-based studies have been undertaken in freshwater tidal wetlands. Furthermore, studies that measured sediment deposition in newly created wetlands are also sparse. This paper aims to identify the factors controlling the sediment trapping of two newly created freshwater tidal wetlands.

Materials and methods Two recently re-opened polder areas in the Biesbosch, The Netherlands are used as study area. Field measurements of water levels, flow velocities, and turbidity at both the in- and outlet of the areas were carried out to determine the sediment budgets and trapping efficiencies under varying conditions of river discharge, tide, and wind in the period 2014-2016.

Results and discussion Short-term sediment fluxes of the two study areas varied due to river discharge, tide, and wind. A positive sediment budget and trapping efficiency was found for the first study area, which has a continuing supply of river water and sediment. Sediment was lost from the second study area which lies further from the river and had a lower sediment supply. The daily sediment
\end{abstract}

Responsible editor: Jose Andres Lopez Tarazon

Electronic supplementary material The online version of this article (doi:10.1007/s11368-017-1729-x) contains supplementary material, which is available to authorized users.

Eveline C. van der Deijl

E.C.vanderDeijl@uu.nl

1 Faculty of Geosciences, Universiteit Utrecht, Utrecht, The Netherlands budget is positively related to upstream river discharge, and in general, export takes place during ebb and import during flood. However, strong wind events overrule this pattern, and trapping efficiencies decrease for increasing wind strengths at mid-range river discharges and for the highest river discharges due to increased shear stress.

Conclusions Delta restoration, based on sedimentation to compensate for sea-level rise and soil subsidence, could only be effective when there is a sufficient supply of water and sediment. Management to enhance the trapping efficiency of the incoming sediment should focus on directing sufficient river flow into the wetland, ensuring the supply of water and sediment within the system during a tidal cycle, creating sufficiently large residence time of water within the polder areas for sediment settling, and decreasing wave shear stress by the establishment of vegetation or topographic irregularities.

Keywords Restoration - River deltas - Sediment budgets . Suspended sediment $\cdot$ Tidal wetlands · Trapping efficiency

\section{Introduction}

Under natural conditions, deltas are dynamic, riverdominated systems, which drown or aggradate in response to changes in environmental conditions (Giosan et al. 2013). Both sedimentation and organic soil formation by vegetation contribute to elevation gain and delta aggradation (Reddy and DeLaune 2008; Calvo-Cubero et al. 2013; Kirwan and Megonigal 2013; Schile et al. 2014). However, many deltas are threatened by drowning due to sea-level rise, human-induced accelerated soil subsidence, sediment starvation due to upstream land use and river management, or increased river discharge (Ibáñez et al. 1997; Syvitski and 
Saito 2007; Syvitski 2008; Syvitski et al. 2009; Giosan et al. 2014; Ibáñez et al. 2014; Day et al. 2016). Since most deltas are densely populated and considered as valuable because of their inherent ecological value and the ecosystem services they provide (Kirwan and Megonigal 2013; Ibáñez et al. 2014), it is essential to prevent them from drowning.

Traditionally, river delta management encompasses hard engineering measures including the construction of artificial structures, such as dikes and dams that protect deltas from flooding. Although these structures successfully reduce flood risks, they disrupt morphodynamic processes and ecological functioning of the system and involve high costs for construction and maintenance (Hudson et al. 2008). Therefore, it is now often considered to shift the management to soft engineering measures that aim at a more natural and multifunctional system where dynamic hydrological, morphological, and ecological processes are restored. Paola et al. (2011) defined river delta restoration as "diverting sediment and water from major channels into adjoining drowned areas, where the sediment can build new land and provide a platform for regenerating wetland ecosystems." This type of river delta restoration is currently considered or implemented in the Tidal River Management project in Bangladesh (Khadim et al. 2013), the diversion projects in the Mississippi deltaic plain (DeLaune et al. 2003; Day et al. 2007; Paola et al. 2011) or in the Atchafalaya subdelta (Roberts et al. 2015; DeLaune et al. 2016), and the Plan Integrale de Protección del Delta Ebro for the Ebro Delta (Calvo-Cubero et al. 2013).

Delta restoration by means of the creation of new wetlands, whereby sedimentation and organic soil formation compensates for sea-level rise and soil subsidence, could be an effective approach as demonstrated by natural cases in the historical past. For example, the Biesbosch area in The Netherlands, inundated due to dike breaches during two storm surges and river floods in the beginning of the fifteenth century that has effectively trapped all the sand transported by the river Rhine in the subsequent centuries (Kleinhans et al. 2010). The Saeftinghe area, an intertidal area located in the brackish zone of the Scheldt estuary, The Netherlands, forms another example. This area has developed from bare tidal flats to a 1-m higher vegetated marsh within 70 years after the inundation in the late sixteenth century (Vandenbruwaene et al. 2013). A recent example is Polder 32, which is located on the tidal delta plain of southwest Bangladesh. This polder area has received tens of centimetres of newly deposited sediment after dike breaches and inundation by the Cyclone Aila in 2009 (Auerbach et al. 2015). Increased vertical marsh accretion is also found in several delta restoration projects. For example, the Breton Sound estuary was restored by diverting water from the Mississippi River (DeLaune et al. 2003). However, the weir management in marsh areas in coastal LA, USA, (Reed
1992) and the impoundments with water-control structures in the Mississippi deltaic plain, USA (Reed et al. 1997) are examples of river delta restoration that cause a decrease in aggradation.

To assess the effectiveness of delta restoration, quantitative knowledge about the aggradation rates and a thorough understanding of mechanisms controlling sedimentation and erosion in wetlands are vital. Previous studies have indicated that sediment deposition in wetlands is controlled by various factors including the flooding frequency, depth, and duration (French and Spencer 1993; Middelkoop and van der Perk 1998; Reed et al. 1999; Temmerman et al. 2003; Thonon et al. 2007; Schuerch et al. 2013), the surface area of the wetland, the suspended sediment load (French and Spencer 1993; Asselman and Middelkoop 1998; Morse et al. 2004; Noe et al. 2016), and the ability of sediment to settle, which in turn, depends on sediment flow paths (French and Spencer 1993; Siobhan Fennessy et al. 1994; Reed et al. 1999; Davidson-Arnott et al. 2002; Temmerman et al. 2003; Anderson and Mitsch 2007; Mitsch et al. 2014), wind (Orson et al. 1990; Delgado et al. 2013), and vegetation (Darke and Megonigal 2003; Temmerman et al. 2005; Schile et al. 2014; Mitsch et al. 2014). These studies were mainly conducted in salt marshes or river flood plains; only few field-based studies were undertaken in freshwater tidal wetlands that represent the transition between these environments. Furthermore, studies that measured sediment deposition in newly created wetlands are also sparse.

This paper aims to identify the factors controlling the sediment trapping of freshwater tidal wetlands. We use two recently re-opened polder areas in the Biesbosch, The Netherlands, as study area, taking advantage of the differences in geographical setting and boundary conditions of the two nearby wetland areas that are similar in climate conditions and tidal range. We measured water levels, flow velocities, and turbidity at both the in- and outlet of the areas to determine the sediment budgets and trapping efficiencies under varying conditions of discharge, tide, and wind.

\section{Materials and methods}

\subsection{Area description}

The Biesbosch (see Fig. 1a, b) comprises a 9000 ha wetland in the lower Rhine and Meuse delta in the southwest of The Netherlands. In the nineteenth century, large parts of the wetland were embanked and reclaimed as polders for agriculture (De Bont C et al. 2000; Noordwaard 2006; Noord-Brabant 2009). The Biesbosch has become a completely human-regulated area by local drainage and water level control of the polders, upstream weir management, and the management of the downstream Haringvliet storm-surge 

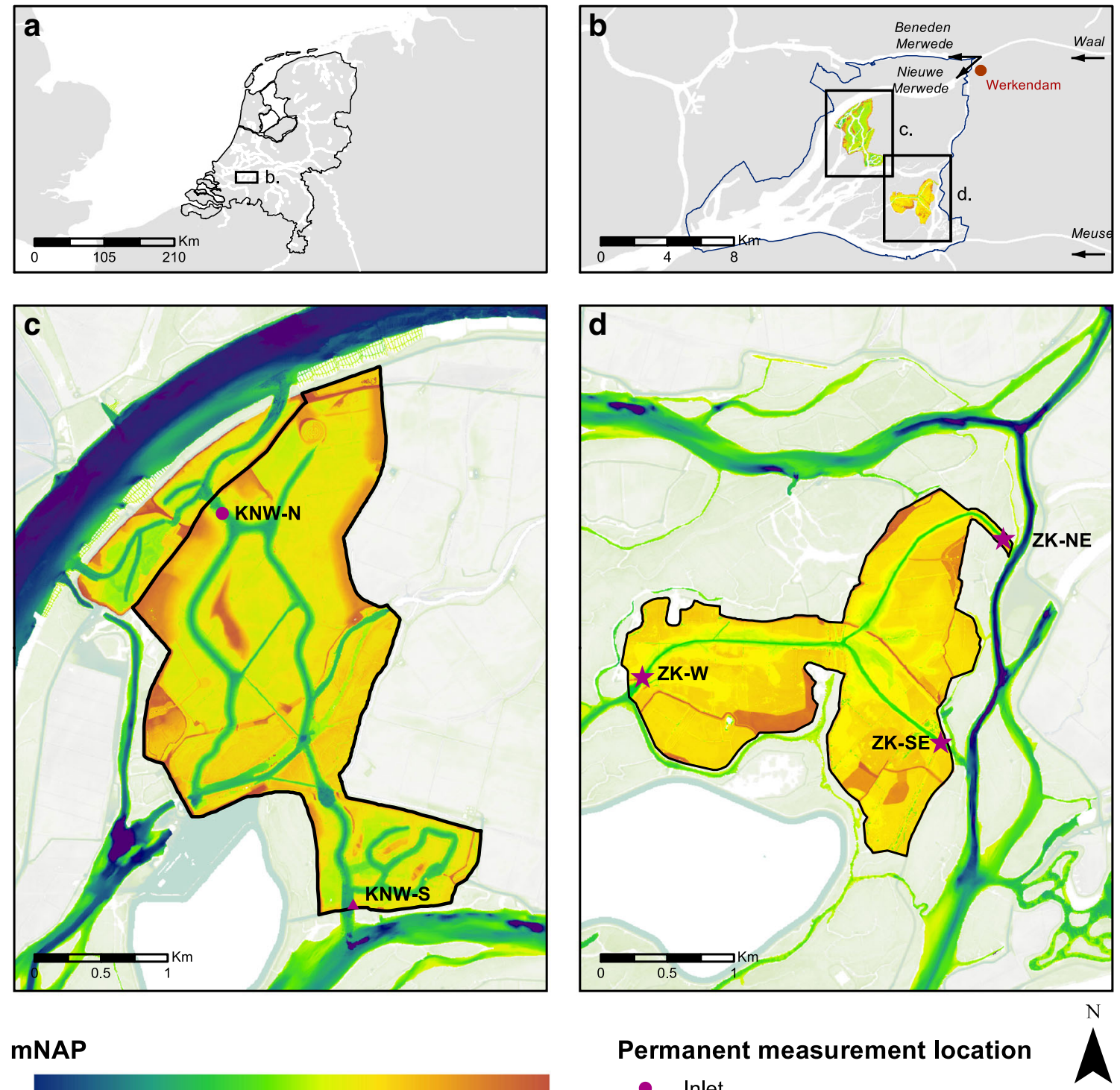

mNAP

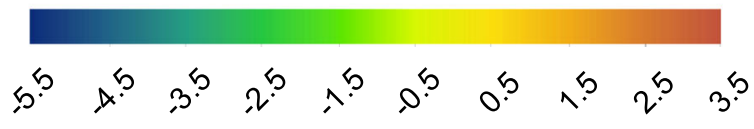

- Inlet

- Outlet

$\star \quad$ Inlet and Outlet

Fig. 1 The location and elevation of, and the location of, the permanent monitoring locations in the Kleine Noordwaard (a, c) and Zuiderklip (b, d) study areas

barrier, that has been operational since 1970, as part of the Delta Project to protect the lower lying Netherlands against the sea (Rijkswaterstaat 2011).

The latest developments in the water management of the Biesbosch area comprises the Room for the River (RfR) initiative, a large national flood prevention programme to improve the discharge capacity as well as the economic and environmental quality of the Dutch rivers (Rijkswaterstaat Ruimte voor de Rivier 2016). In the framework of the RfR initiative, water and sediment have been reintroduced in several previously embanked areas of the Biesbosch. We studied the sediment trapping of two of these areas: Kleine Noordwaard (Fig. 1c) and Zuiderklip (Fig. 1d).
The Kleine Noordwaard study area was depoldered in May 2008 by connecting the inlet in the North (KNW$\mathrm{N}$ in Fig. 1c) to the Nieuwe Merwede, a branch of the River Waal, which is, in turn, the major distributary of the River Rhine. The River Rhine has an average discharge of $2200 \mathrm{~m}^{3} \mathrm{~s}^{-1}$ and an average suspended sediment concentration of $15 \mathrm{mg} \mathrm{l}^{-1}$ at the German-Dutch border located $85 \mathrm{~km}$ upstream from the Kleine Noordwaard. In the Kleine Noordwaard, the major flow direction is from north to south and water and sediment leave the area through the outlet in the south (KNW-S in Fig. 1c). The channels in the Kleine Noordwaard study area were constructed with a width of $120 \mathrm{~m}$, a maximum depth of $3 \mathrm{~m}$ and lateral slopes of 
$1: 20$. A bridge restricts the channel at the inlet of the study area to a width of $75 \mathrm{~m}$ and a maximum depth of $2.5 \mathrm{~m}$. Alongside the channels 150-300-m wide intertidal areas are present, which have an elevation of $0.3-0.7 \mathrm{~m}$ above the Dutch Ordnance Datum (NAP) (Noordwaard 2006). The sandy material, which was dug out of the channels, was used to create islands or to protect the remaining dikes. The area is composed of deep open water (18\%), mud flats $(31 \%)$, and a terrestrial zone (51\%).

The Zuiderklip study area is located further away from the rivers Rhine and Meuse. The area was depoldered in 2011. There are three connections to surrounding channels and there is a water divide in the middle of the area. The channel in the south-east (ZK-SE in Fig. 1d) is the major inlet, the channel in the west (ZK-W in Fig. 1d) is the major outlet, and the channel in the north-east (ZK-NE in Fig. 1d) is a minor outlet of the area. The major inlet $\mathrm{ZK}-\mathrm{SE}$ is connected to a branch of the River Meuse, which supplies the water and sediment. The river Meuse has a mean discharge of $230 \mathrm{~m}^{3} \mathrm{~s}^{-1}$ and an average suspended sediment concentration of $15 \mathrm{mg} \mathrm{l}^{-1}$ at the Eijsden monitoring station near the Belgian-Dutch border located $250 \mathrm{~km}$ upstream from the study area. The channels in the Zuiderklip study area are narrower and shallower than the Kleine Noordwaard channels. They have a width of 60 to $90 \mathrm{~m}$, a maximum depth of $2.2 \mathrm{~m}$, and lateral slopes of 1:3 to $1: 20$. The intertidal areas are about $100 \mathrm{~m}$ wide and have an elevation of $0.5 \mathrm{~m}$ above NAP (Noord-Brabant 2009). The area is composed of deep open water $(9 \%)$, mud flats $(56 \%)$, and a terrestrial zone $(35 \%)$.

Water levels in the Biesbosch area are influenced by the tide, which has a range of approximately 0.2 to $0.4 \mathrm{~m}$ (according to the water level measurements by Rijkswaterstaat (2016)), wind direction and speed (measured by Royal Netherlands Meteorological Institute (KNMI 2016) at the surrounding measurement locations Rotterdam, Gilze-Rijen and Herwijnen), the discharge of the rivers Rhine and Meuse, and the artificially controlled discharge through the gates of the downstream Haringvliet barrier into the North Sea.

Both areas have been depoldered to increase the discharge capacity of the rivers. To reduce the hydraulic roughness of the areas, the dry parts are mowed before the winter period and most of the vegetation is effectively shortened through grazing by birds, horses, and cows. The vegetation in the majority of the terrestial zone can be classified as dry and damp grasslands with at the shoreline some Mentha aquatica, Schoenoplectus triqueter, and Bolboschoenus maritimus. The mud flats are almost bare with some pioneer species such as Hydrodictyon reticulatum, Limosella aquatica, Veronica anagallis-aquatica, and Pulicaria vulgaris. In the summer, there is locally some Myriophyllum spicatum in open water (De la Haye 2011, 2012). Table 1 summarises
Table 1 Characteristics of Kleine Noordwaard and Zuiderklip study areas

\begin{tabular}{lll}
\hline & Kleine Noordwaard & Zuiderklip \\
\hline Depoldered in & May 2008 & 2011 \\
Surface area & $5.2 \mathrm{~km}^{2}$ & $3.45 \mathrm{~km}^{2}$ \\
Channel bed level & $-2 \mathrm{mNAP}$ & $-1.75 \mathrm{mNAP}$ \\
Channel width & $120 \mathrm{~m}$ & $60-90 \mathrm{~m}$ \\
Channel side slope & $1 / 20$ & $1 / 3-1 / 20$ \\
Intertidal area width & $150-300 \mathrm{~m}$ & $100 \mathrm{~m}$ \\
Intertidal area height & $0.3-0.7 \mathrm{mNAP}$ & $0.5 \mathrm{mNAP}$ \\
River & River Rhine $_{\text {Rer }}$ & River Meuse \\
Q $_{\text {year }}{ }^{-1}$ & $5800 \mathrm{~m}^{3} \mathrm{~s}^{-1}$ & $1200 \mathrm{~m}^{3} \mathrm{~s}^{-1}$ \\
Q $_{\text {avg }}$ & $2200 \mathrm{~m}^{3} \mathrm{~s}^{-1}$ & $230 \mathrm{~m}^{3} \mathrm{~s}^{-1}$ \\
SSC $_{\text {lyear }}{ }^{-1}$ & $260 \mathrm{mg} \mathrm{l}^{-1}$ & $420 \mathrm{mg} \mathrm{l}^{-1}$ \\
SSC $_{\text {avg }}$ & $14.8 \mathrm{mg} \mathrm{l}^{-1}$ & $15.3 \mathrm{mg} \mathrm{l}^{-1}$ \\
\hline
\end{tabular}

the main characteristics and differences of the two study areas.

\subsection{Field methods}

\subsubsection{Permanent monitoring locations}

For this study, permanent monitoring locations were installed at all in- and outlets of the study areas (Fig. 1c, d). Average water level, flow velocity, and turbidity were recorded at all locations at a 10-min interval. Water levels were measured by Vegawell 52 pressure sensors, turbidity by Seapoint Turbidity Meters (STMs), and flow velocities by Horizontal Acoustic Doppler Profilers (HADCPs), installed at approximately $30-40 \%$ of the average water depth. Flow velocities in $x$ and $y$ direction with an accuracy of $5 \mathrm{~mm} \mathrm{~s}^{-1}$ were measured in nine 1.25-3.00-m-wide cells by two OTT Side looking Doppler profilers of $600 \mathrm{kHz}$ for the permanent monitoring locations (KNW-N) and (KNW$\mathrm{S}$ ) in Kleine Noordwaard, and by three NORTEK Aquadopp 1-MHz sensors for the locations ZK-W, ZK-NE and ZK-SE in Zuiderklip. A solar panel was used for power supply, and all data were transferred to a server once an hour. Because of algal growth, the turbidity measurements were only reliable when the STM sensors were regularly cleaned. Turbidity measurements including the cleaning of the sensors in the Kleine Noordwaard took place between July 2014 and April 2015 and in the Zuiderklip between July 2015 and March 2016.

Additional field campaigns were implemented to acquire suspended sediment concentrations and measurements of total channel discharge. These measurements were used for calibration of the HADCP and STM sensors to obtain time series of channel discharge and suspended sediment concentration for each monitoring location. For details about 
the methods and results of the calibration of the HADCP and STM sensors, we refer to Electronic Supplementary Material 1.

The calibrated channel discharge and suspended sediment concentrations allowed the calculation of the total flux of suspended sediment at all permanent monitoring locations as the product of the channel discharge and SSC. Furthermore, the sediment budgets of the study areas were calculated as the difference between the incoming and outgoing flux, since accretion due to production of soil organic material is negligible. The trapping efficiency is defined as the sediment budget, i.e. the amount of sediment that has entered the area minus the amount of sediment that left the area, divided by the incoming sediment. This means that positive trapping efficiencies indicate the effectiveness of the area to trap and store incoming sediment, while negative trapping efficiencies represent the magnitude of the sediment loss with respect to the incoming sediment.

\subsection{Relation to controlling factors}

To assess the effects of discharge, tide, and wind on sediment trapping, independent measurements of the upstream river discharge, upstream SSC, wind direction, and wind speed were used. Daily measurements of upstream river discharge and SSC at the monitoring locations Lobith (River Rhine at the German-dutch border, $85 \mathrm{~km}$ upstream) and Eijsden (River Meuse at the Belgian Dutch border, $250 \mathrm{~km}$ upstream) were provided by Rijkswaterstaat (2016). Hourly measurements of wind direction and speed at the surrounding measurement locations Rotterdam, GilzeRijen, and Herwijnen were provided by the Royal Dutch
Meteorological Institute (KNMI 2016). The representativeness of the wind and discharge conditions of the monitoring periods for the prediction of the short term sediment budgets and controlling factors since the opening of the polder areas was checked by comparing the statistical wind and discharge distributions for both the monitoring period and the entire period since depoldering of the study areas. Subsequently, the upstream discharge and wind data were related to the observed suspended sediment concentrations, fluxes, and budgets in the study area.

\section{Results}

\subsection{Representativeness of monitoring periods}

Figure 2 shows the exceedance probability (PE) of the upstream river discharge $\left(\mathrm{Q}_{R}\right)$ and suspended sediment concentrations $\left(\mathrm{SSC}_{R}\right)$ for the two study areas both for the monitoring period and the entire period after depoldering. Figure $2 \mathrm{a}, \mathrm{b}$ indicates that the range of the observed $\mathrm{Q}_{R}$ and $\mathrm{SSC}_{R}$ in the Kleine Noordwaard is smaller for the monitoring period than for the entire period since depoldering. The $10 \%$ lowest river discharges (between 840 and $1300 \mathrm{~m}^{3} \mathrm{~s}^{-1}$ ) and the $5 \%$ highest river discharges of $>4570 \mathrm{~m}^{3} \mathrm{~s}^{-1}$ are missing in the monitoring period. Furthermore, the low river discharges (1700-3000 $\mathrm{m}^{3} \mathrm{~s}^{-1}$ ) are overrepresented during the monitoring period. A Kolmogorov-Smirnov test shows that the difference between cumulative distribution of the $\mathrm{PE}$ of $\mathrm{Q}_{R}$ during the monitoring period and that during the entire period after depoldering is statistically significant at the 5\% level $\left(p=4.0310^{-8} ; N=233 ; \mathrm{K}-\mathrm{S}\right.$ test statistic $=$
Fig. 2 Exceedance probability of the upstream river discharge and suspended sediment concentration for the entire period after depoldering (blue) and the monitoring period (red) for the Kleine Noordwaard (a, c) and Zuiderklip (b, d). Note the different scale of the $x$-axes for the two study areas
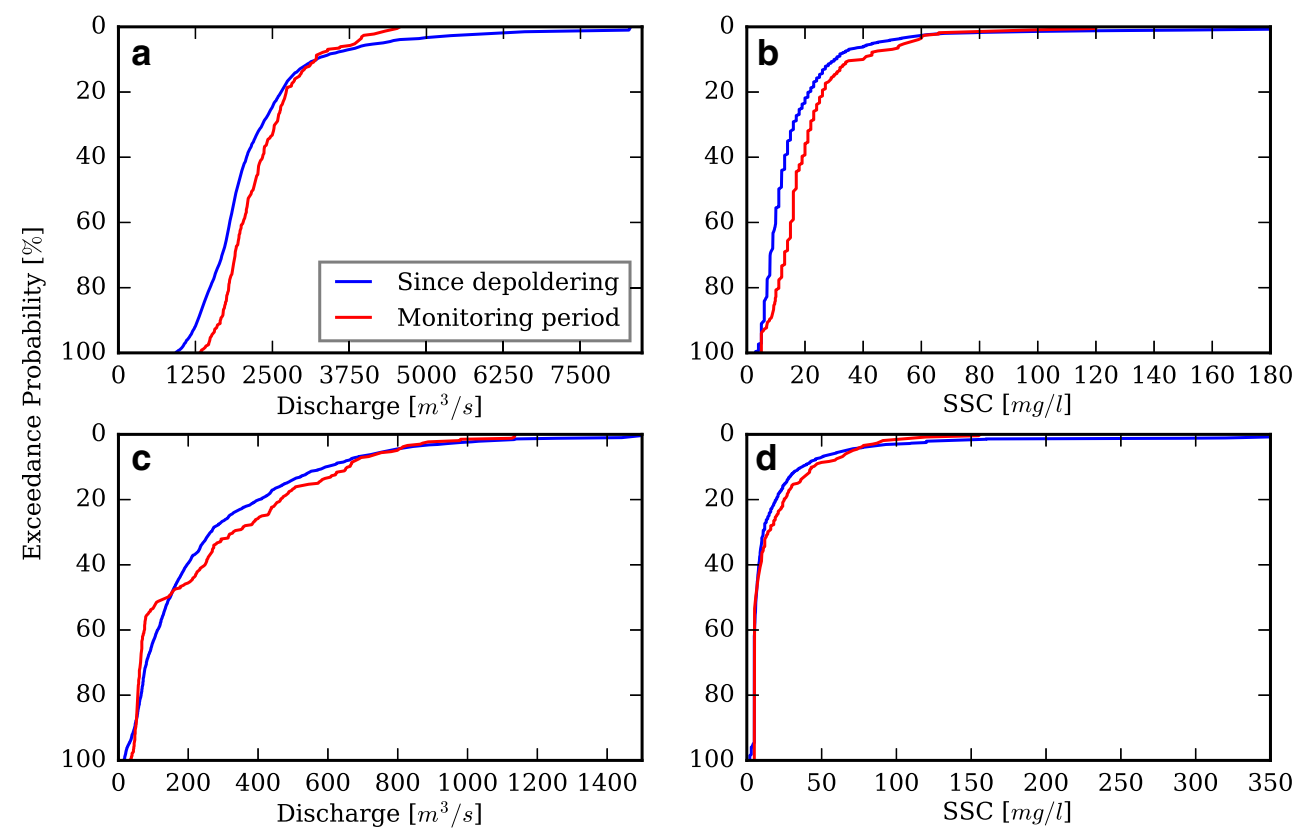
0.20). A similar pattern is observed for $\mathrm{SSC}_{R}$. The $\mathrm{SSC}$ is positively related to discharge. The SSCs below $14 \mathrm{mg} \mathrm{l}^{-1}$ and above $60 \mathrm{mg} \mathrm{l}^{-1}$ are underrepresented during the monitoring period, whereas the SSCs between 14 and $28 \mathrm{mg}$ $1^{-1}$ are overrepresented. The difference between cumulative distributions of the $\mathrm{PE}$ of $\mathrm{SSC}_{R}$ during the monitoring period and the the entire period after depoldering is also statistically significant at the 5\% level $\left(p=8.3410^{-19} ; N=\right.$ 233 ; K-S test statistic $=0.31$ ).

For the Zuiderklip area, the distributions of the $\mathrm{Q}_{R} \mathrm{e}$ and $\mathrm{SSC}_{R}$ of the monitoring period and entire period since depoldering are more similar. The Kolmogororv-Smirnov test shows that the discharge distributions differ significantly at the 5\% level $\left(p=1.5110^{-4} ; N=269 ; \mathrm{K}-\mathrm{S}\right.$ statistic $=0.14)$, but the SSC distributions do not signifcantly differ $(p=0.19 ; N=269 ; \mathrm{K}-\mathrm{S}$ statistic $=0.07)$. Figure 2c, d shows the $\mathrm{PE}$ for $\mathrm{Q}_{R}$ and $\mathrm{SSC}_{R}$ of the Zuiderklip area. Although the minimum $\mathrm{Q}_{R}$ was observed during the monitoring period, there is a relatively small number of discharges below $200 \mathrm{~m}^{3} \mathrm{~s}^{-1}$ and a relatively large number of discharges between $200-280 \mathrm{~m}^{3} \mathrm{~s}^{-1}$ and over 600 $\mathrm{m}^{3} \mathrm{~s}^{-1}$. The maximum discharge observed during the monitoring period was $1137 \mathrm{~m}^{3} \mathrm{~s}^{-1}$, which means that the $1.5 \%$ highest discharges are not included in the monitoring period. For the $\mathrm{SSC}_{R}$, concentrations between 5 and $7 \mathrm{mg} \mathrm{l}^{-1}$ were observed more frequently, while the higher concentrations were observed less frequently during the monitoring period, than during the entire period since depoldering. The highest $1.8 \%$ of $\mathrm{SSC}_{R}$ is missing in the monitoring period.

Figure 3 shows the wind roses for both the entire period after depoldering and the monitoring period for the Kleine
Noordwaard and Zuiderklip study areas. Compared to the entire period after depoldering, S-SWW and $\mathrm{N}$ wind events are somewhat overrepresented, and NW wind events are slightly underrepresented during the monitoring period for the Kleine Noordwaard area. During the Zuiderklip monitoring period, strong SSW-SWW events were observed. However, Watson's $U^{2}$ tests show the difference between the azimuth of the wind directions for the entire period after depoldering and that of the monitoring period is not significantly different for both the Kleine Noordwaard $(p=6.85$ $10^{-125} ; N=33332 ; \mathrm{U} 2$ statistic $\left.=0.082\right)$ and Zuiderklip $(p$ $=1.6410^{-287} ; N=42211 ; \mathrm{U} 2$ statistic $\left.=0.11\right)$ study areas. Therefore, we conclude that the wind conditions during the monitoring periods are representative for the entire period after depoldering.

Based on this analysis, it can be concluded that sediment fluxes for longer periods may be underestimated, since events with high discharge and suspended sediment concentrations with return periods considerably greater than the monitoring period are missing in the observed time series.

\subsection{Data pre-processing}

\subsubsection{Time series of water level, discharge, and SSC}

Figure 4 shows the time series of water level, channel discharge, and suspended sediment concentration for all permanent monitoring locations in the Kleine Noordwaard (a) and Zuiderklip (b) study areas. The incoming discharge at the inlet KNW-N is on average $89 \mathrm{~m}^{3} \mathrm{~s}^{-1}$ during flood tide with a maximum of $191 \mathrm{~m}^{3} \mathrm{~s}^{-1}$ during a discharge
Fig. 3 Wind roses the entire period after depoldering $(\mathbf{a}, \mathbf{b})$ and the monitoring period $(\mathbf{c}, \mathbf{d})$ for the Kleine Noordwaard (a, c) and Zuiderklip (b,d) study areas

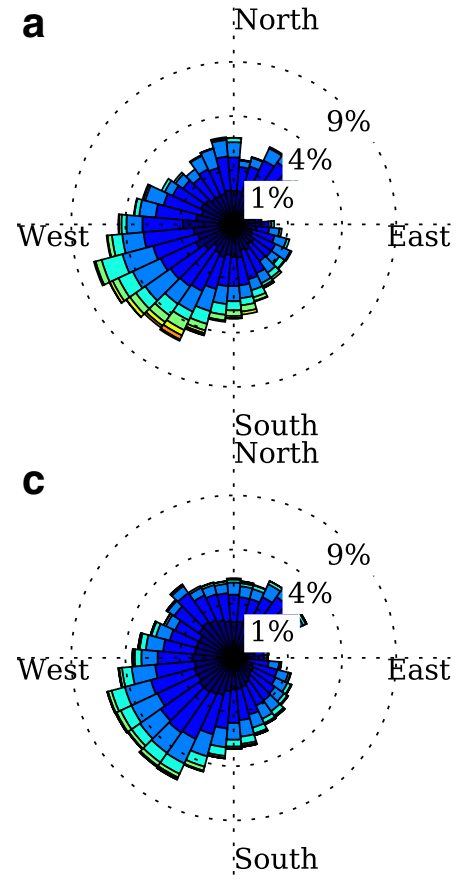

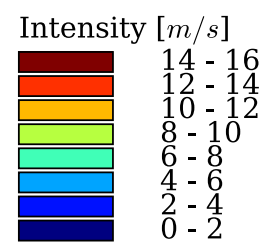



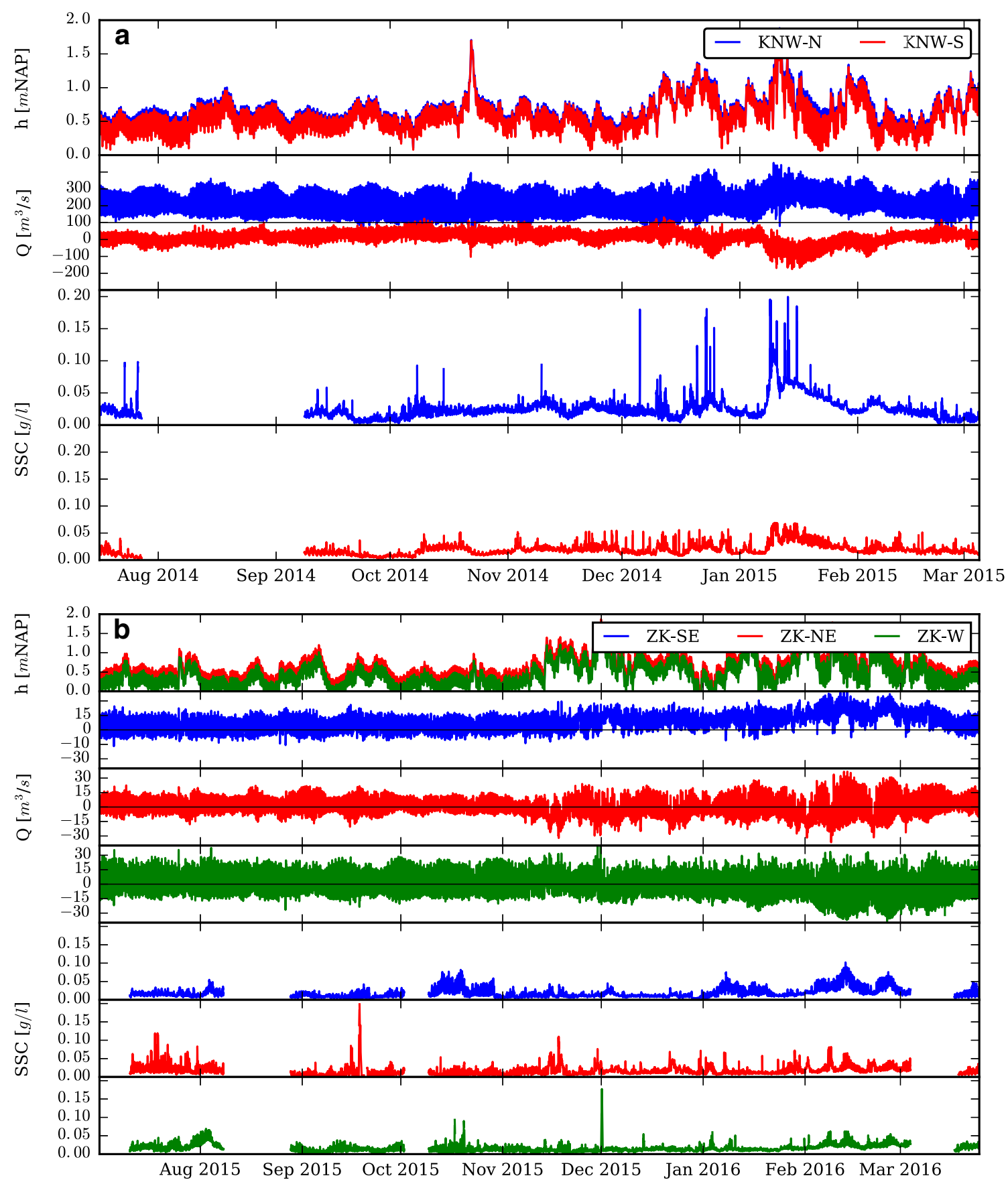

Fig. 4 Time series of water level, channel discharge (Q, positive into the study area), and suspended sediment concentration (SSC) for all permanent monitoring locations in the Kleine Noordwaard (a) and Zuiderklip (b) study areas. Parts of the SSC data were omitted from

event. During ebb tide the outgoing discharge is on average $11 \mathrm{~m}^{3} \mathrm{~s}^{-1}$ with a maximum of $40 \mathrm{~m}^{3} \mathrm{~s}^{-1}$. At KNW-S, water is in general exported with an average discharge of $86 \mathrm{~m}^{3} \mathrm{~s}^{-1}$ and a maximum of $178 \mathrm{~m}^{3} \mathrm{~s}^{-1}$. Import, with a maximum of $16 \mathrm{~m}^{3} \mathrm{~s}^{-1}$, only takes place when the water level rises rapidly at the onset of flood tide. The incoming discharge at the inlet, the average water depth, and the time series when the signal of one of the turbidity sensors was obscured by algal growth. Note the different scale of the $y$-axis of the discharge for the two study areas

the wet surface area have been used to calculate the water residence time in the Kleine Noordwaard study area. The residence time, calculated based on the incoming discharge at the inlet, the average water depth, and the wet surface area, is on average $10 \mathrm{~h}$. and $8 \mathrm{~min}$. at an average water depth of $0.97 \mathrm{~m}$, but it varies between $5 \mathrm{~h} .29 \mathrm{~min}$ (average water depth $=0.98 \mathrm{~m}$ ) and $18 \mathrm{~h} .54 \mathrm{~min}$ (average water 
depth $=1.07 \mathrm{~m}$ ) for the respectively highest and lowest river discharge events in the monitoring period.

In the Zuiderklip study area, there is a larger variation in water flow into or from the study area. However, it is apparent that in general water is imported at ZK-SE, with an average of $9 \mathrm{~m}^{3} \mathrm{~s}^{-1}$ and a maximum of $24 \mathrm{~m}^{3} \mathrm{~s}^{-1}$ during flood and exported with an average of $3 \mathrm{~m}^{3} \mathrm{~s}^{-1}$ and a maximum of $8 \mathrm{~m}^{3} \mathrm{~s}^{-1}$ during ebb, and that most of the water in Zuiderklip is supplied through this inlet. Water is in general exported at ZK-NE $\left(6 \mathrm{~m}^{3} \mathrm{~s}^{-1}\right.$ to a maximum of $22 \mathrm{~m}^{3}$ $\left.\mathrm{s}^{-1}\right)$ and $\mathrm{ZK}-\mathrm{W}\left(10 \mathrm{~m}^{3} \mathrm{~s}^{-1}\right.$ to a maximum of $\left.29 \mathrm{~m}^{3} \mathrm{~s}^{-1}\right)$, but import takes place (on average $7 \mathrm{~m}^{3} \mathrm{~s}^{-1}$ and $10 \mathrm{~m}^{3} \mathrm{~s}^{-1}$ for $\mathrm{ZK}-\mathrm{NE}$ and $\mathrm{ZK}-\mathrm{W}$ ) when water levels rise during flood. The inflow of water at these locations occurs more often in summer, when the mean water level is lower, than during winter. Because of the lower incoming river discharge, the shallower intertidal area, and a similar wet surface area, the residence time of water in the Zuiderklip area is larger than in the Kleine Noordwaard. The residence time is on average $23 \mathrm{~h}$ and $25 \mathrm{~min}$ at an average water depth of $0.61 \mathrm{~m}$ but varies between $9 \mathrm{~h} 3 \mathrm{~min}$ (average water depth $=0.92 \mathrm{~m}$ ) and $39 \mathrm{~h} 28 \mathrm{~min}$ (average water depth $=0.50 \mathrm{~m}$ ) for the respectively highest and lowest river discharge events in the monitoring period.

The time series of SSC indicate that in general the highest concentrations of the Kleine Noordwaard, occur at location KNW-N, the main inlet of the area, which receives the water and sediment of the River Rhine. The average concentration at location $\mathrm{KNW}-\mathrm{N}$ is $26 \mathrm{mg}^{-1}$ and the maximum is $114 \mathrm{mg} \mathrm{l}^{-1}$, while it is on average $19 \mathrm{mg} \mathrm{l}^{-1}$, with a maximum of $62 \mathrm{mg} \mathrm{l}^{-1}$ at location KNW-S. The average concentration of $19 \mathrm{mg} \mathrm{l}^{-1}$ and the maximum concentration of $69 \mathrm{mg}^{-1}$ measured at the main inlet of the Zuiderklip area (ZK-SE) are about the same as measured at the main outlet of the area (ZK-W), where the average and maximum concentrations were 17 and $96 \mathrm{mg} \mathrm{l}^{-1}$, respectively. Furthermore, it is apparent that the incoming suspended sediment concentrations are in general higher at the Kleine Noordwaard than at the Zuiderklip study area.

\subsection{Sediment budget}

\subsubsection{Total budget}

Figure 5 depicts the cumulative sediment budget together with the discharge at the main inlet (blue line) for the Kleine Noordwaard (a) and Zuiderklip (b) during the monitoring periods. This figure indicates that the Zuiderklip study area experienced a net loss of sediment, while the Kleine Noordwaard area experienced a net gain of sediment. Furthermore, the figure shows that both the cumulative sediment budget and incoming discharge is about 10 times larger for the Kleine Noordwaard than for the Zuiderklip study area. The Kleine Noordwaard trapped approximately $12.4 \mathrm{kt}$ throughout the monitoring period. This corresponds to an average flux of $764 \mathrm{~g} \mathrm{~s}^{-1}$, a total sediment accumulation of $2.38 \mathrm{~kg} \mathrm{~m}^{-2}$, and an average annual area-normalised sediment accumulation rate of $4.77 \mathrm{~kg} \mathrm{~m}^{-2} \mathrm{y}^{-1}$. Based on an average bulk density of fresh and consolidated mud of $1150 \mathrm{~kg} \mathrm{~m}^{-3}$ in the study area (Van der Deijl et al., 2017),

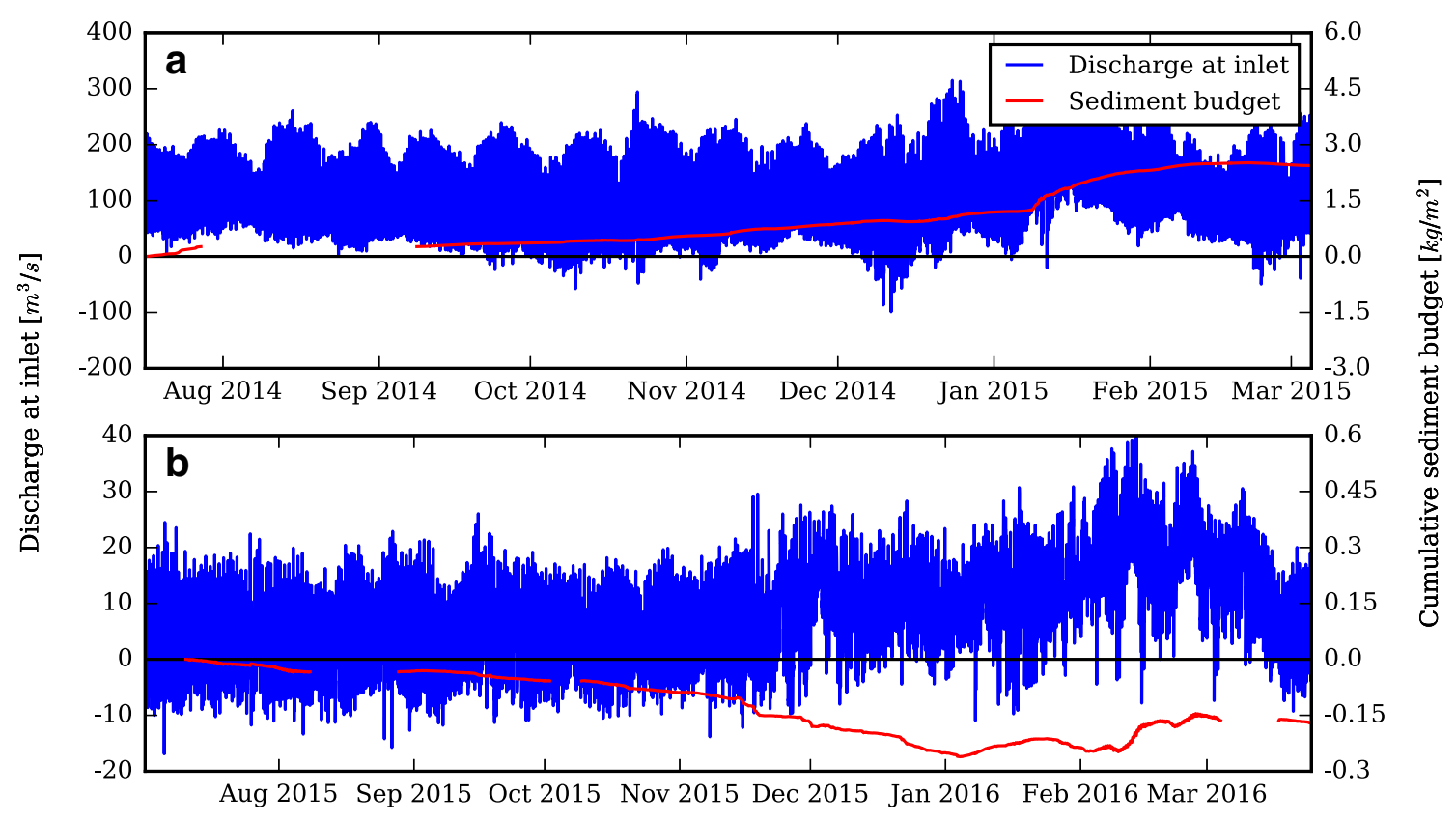

Fig. 5 Cumulative sediment budget (red) and discharge at the monitoring locations at the main inlets of (a) the Kleine Noordwaard (KNW-N) and (b) the Zuideklip (ZK-SE). Note the different scale of the y-axes for the two study areas 
this corresponds to an average sediment accumulation rate of $4.15 \mathrm{~mm} \mathrm{y}^{-1}$.

The Zuiderklip study area has a negative sediment budget of -593 kton throughout the monitoring period, which corresponds to a sediment flux of $-30 \mathrm{~g} \mathrm{~s}^{-1}$, an annual areanormalised sediment loss rate of $-0.28 \mathrm{~kg} \mathrm{~m}^{-2} \mathrm{y}^{-1}$, corresponding to $-0.24 \mathrm{~mm} \mathrm{y}^{-1}$. Although the Zuiderklip area is subject to an overall loss of sediment, sediment import takes place during a rise in the average incoming discharge at the inlet, for example during the moderate discharge event in the first half of January 2016. This trend can also be observed in the Kleine Noordwaard, where a sharp increase in the import occurs when the average incoming discharge rises. Although the Zuiderklip area experiences sediment export when the average incoming discharge decreases at the end of a discharge event, the overall sediment budget during discharge events is positive.

\subsubsection{Controlling factors}

River discharge To analyse the upstream river discharge as controlling factor without the effects of tide, we calculated daily averaged values of SSC, sediment budget, and sediment trapping efficiency. The discharge at the main inlets of the study areas is correlated with the upstream river discharge ( $r=0.72$ for the Kleine Noordwaard/River Rhine and $r=0.62$ for the Zuiderklip/River Meuse). Both the average SSC and the flow weighted mean SSC at the main inlet of the Kleine Noordwaard area $(\mathrm{KNW}-\mathrm{N})$ is larger than at the main inlet of Zuiderklip (ZK-SE). The ratio of the SSC at the inlet and the upstream river is 1.28 for the Kleine Noordwaard and 0.53 for the Zuiderklip area. This indicates that a relatively large fraction of the sediment of the River Meuse is already lost before the river water enters the Zuiderklip study area at the main inlet ZK-SE.

Figure 6 shows the daily averaged sediment budget and the daily averaged trapping efficiency as function of the daily upstream river discharge for both the Kleine Noordwaard and Zuiderklip study areas. Figure 6A and B show that for both study areas the daily sediment budget is positively related to the upstream river discharge. For the Kleine Noordwaard study area, the daily sediment budget is always positive for upstream river discharges above $3000 \mathrm{~m}^{3} \mathrm{~s}^{-1}$. The same threshold is visible in Fig. $6 \mathrm{C}$, which shows that the trapping efficiency of this area is always positive at discharges greater than $3000 \mathrm{~m}^{3} \mathrm{~s}^{-1}$. For the Zuiderklip area, there is no clear threshold, above which both the trapping efficiency and the sediment budget of the area are always positive.

Although the sediment budget increases with river discharge, the daily trapping efficiency only increases for river discharges of less than $3000 \mathrm{~m}^{3} \mathrm{~s}^{-1}$ (Kleine Noordwaard) or $600 \mathrm{~m}^{3} \mathrm{~s}^{-1}$ (Zuiderklip). In both areas, the trapping efficiencies decrease for discharges above these thresholds.

Tide Figure 7 shows the instantaneous 10-minute sediment budget as function of both the daily river discharge and the tidal moment, where red dots indicate flood tide, blue dots ebb tide, and white and grey dots slack water. The regression line between daily averaged sediment budget and river discharge, indicated with the dotted black line, is used as the threshold for the further analysis of the effects of tide. From Fig. 7, it becomes apparent that for both study areas, almost all sediment budgets during flood are positive and above the
Fig. 6 The daily averaged areaspecific sediment budget $(\mathbf{a}, \mathbf{b})$ and trapping efficiency $(\mathbf{c}, \mathbf{d})$ as function of the daily upstream river discharge for the Kleine Noordwaard (River Rhine) (a,c) and Zuiderklip (River Meuse) (b, d) study areas. Note the the different scale of the $x$-axis for the two study areas
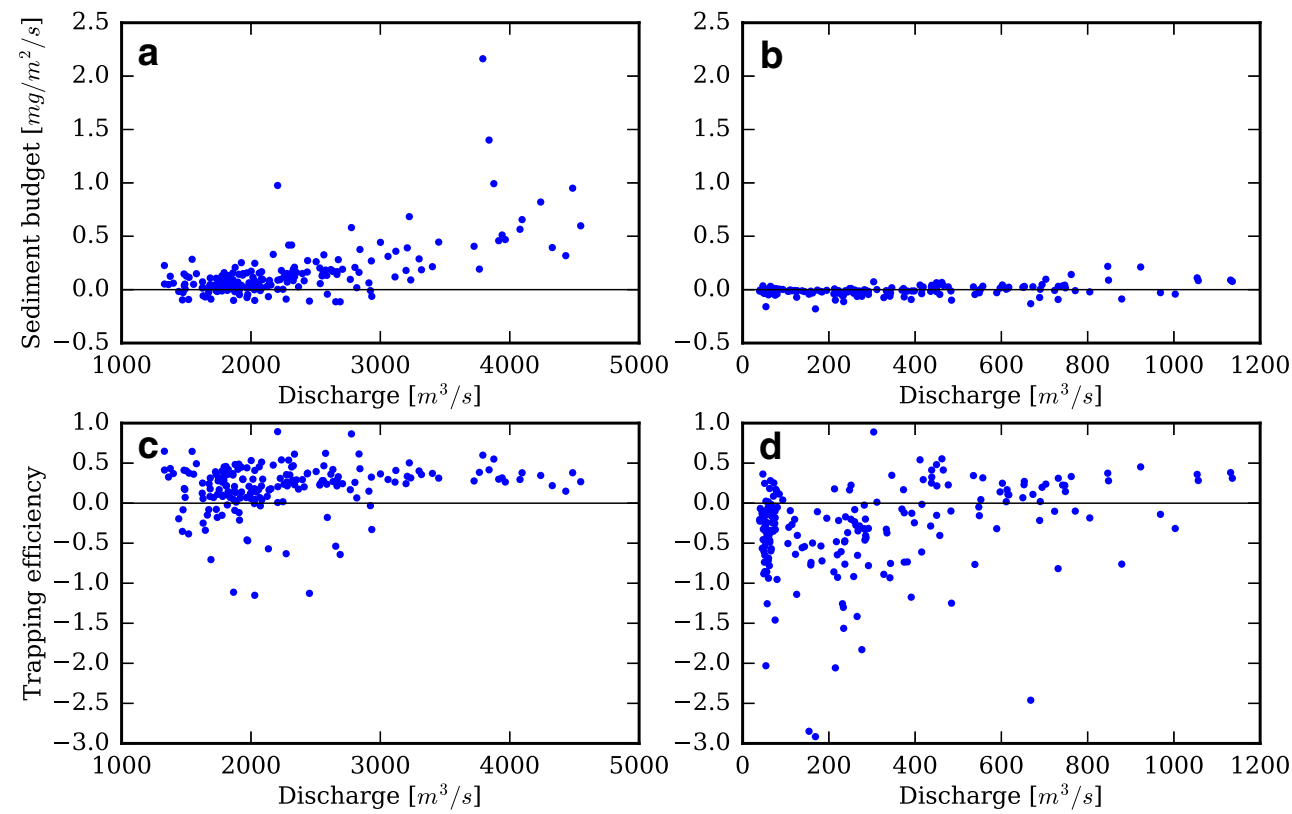

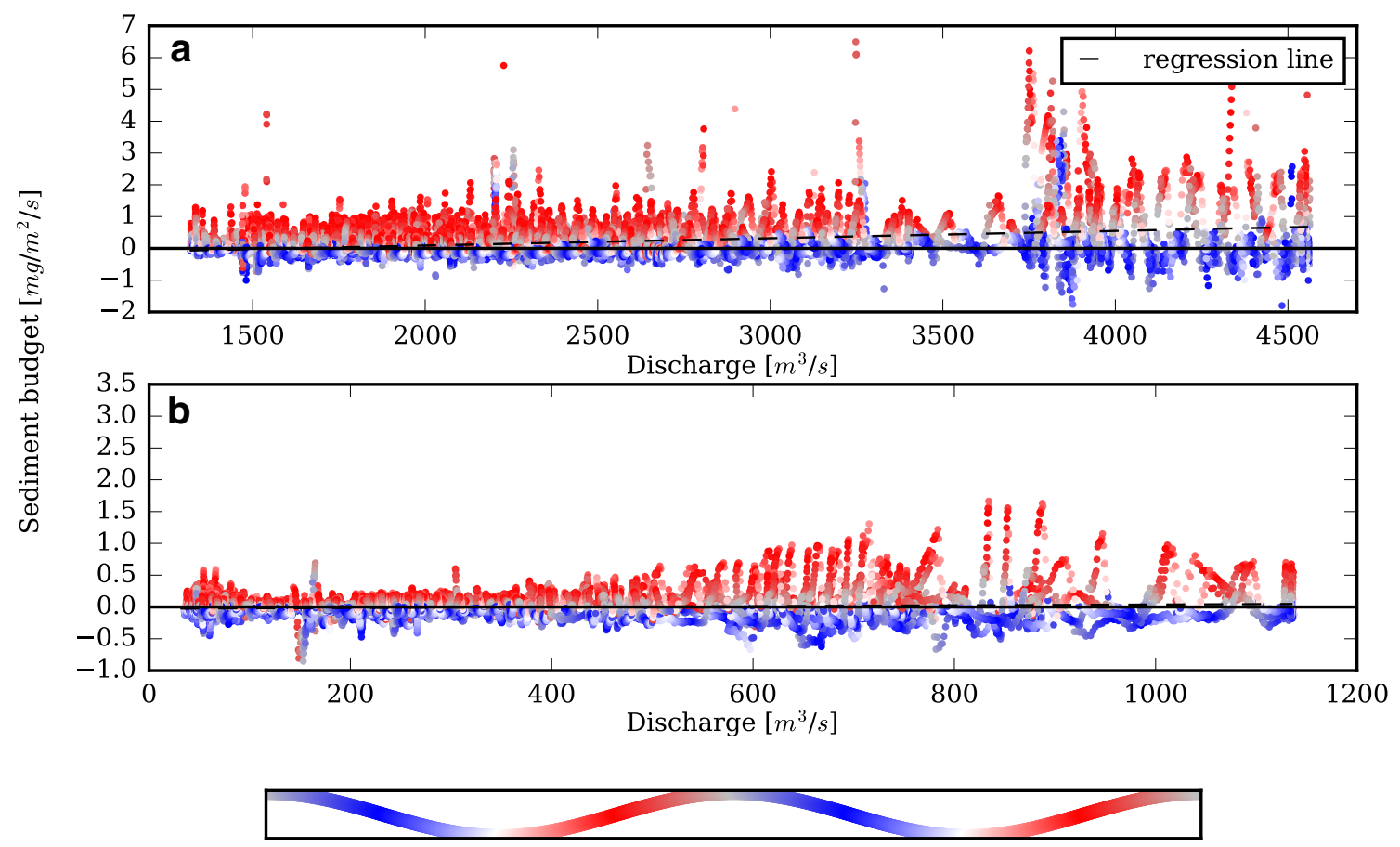

Tidal water level variation

Fig. 7 Ten-minute sediment flux, as function of river discharge (xaxis) and the moment in the tide (dot collor) for the Kleine Noordwaard (a) and Zuiderklip study areas (b). The regression between the daily

regression line. Only under conditions of very low river discharges, negative sediment budgets can be observed during floods. Negative sediments budgets are generally observed during ebb tide. However, for the Kleine Noordwaard, the frequency of positive sediment budgets during ebb increases with increasing river discharges. In these cases, the general trend of export during ebb is overruled by the increased import of sediment at high river discharge. In the Zuiderklip, the sediment budget increases with increasing discharge, both for export during ebb and import during flood. Furthermore, the incoming and outgoing discharge due to tide (as calculated from the water surface area and average tidal range) is only $40 \%$ of the observed mean discharge in the Kleine Noordwaard, whereas this tidal discharge is $63 \%$ of the observed mean discharge in the Zuiderklip. These observations suggest that the tide has a relatively larger effect on the sediment budget in the Zuiderklip area than in the Kleine Noordwaard area.

Wind Despite the general trends observed in the sediment budgets, river discharge, and tide, there are still some outliers visible in Fig. 7. These exceptions include events with net sediment export during flood (red dots with negative sediment budgets below the threshold for river discharge) or import during ebb (blue dots with positive sediment budgets above the threshold for river discharge). We hypothesise that averaged sediment budget and river discharge (see Fig. 6), is indicated by the dashed black line. Note the different scales of the axes for the two study areas)

these exceptions are caused by extreme wind conditions. To test this, we compared the wind conditions during these exceptional situations with the wind conditions during the entire monitoring period (Fig. 8). The wind roses in Fig. 8a, c indicate that in the Kleine Noordwaard, strong SW to NW wind events result in net export during floods. This export cannot be explained by accelerated resuspension due to wind waves, since the SSC observed at the downstream location KNW-S did not increase during these wind events. Figure 8a, e shows that during some NE wind events in the Kleine Noordwaard, import of sediment takes place during ebb. This import is caused by a relatively large increase in the incoming discharge and SSC at the upstream location KNW-N and a relatively small increase in outgoing discharge, combined with a decrease in SSC at the downstream location KNW-S. Figure 8b, d indicate that the stronger SSW to SW wind events may result in export of sediment from the Zuiderklip area during floods. Although the inflow of water increases at the downstream location $\mathrm{ZK}-\mathrm{W}$, the outflow at location ZK-NE also increases, while the inflow of water at the most upstream location ZK-SE is hampered. The decreased inflow at ZK-W and ZK-E causes a net reduction in sediment import because the SSC is generally higher at ZK-W than ZK-SE. Furthermore, the SE wind results in resuspension of sediment in the central part of the area. The increased export of water with elevated SSC at location ZK-NE causes the sediment budget of the Zuiderklip 


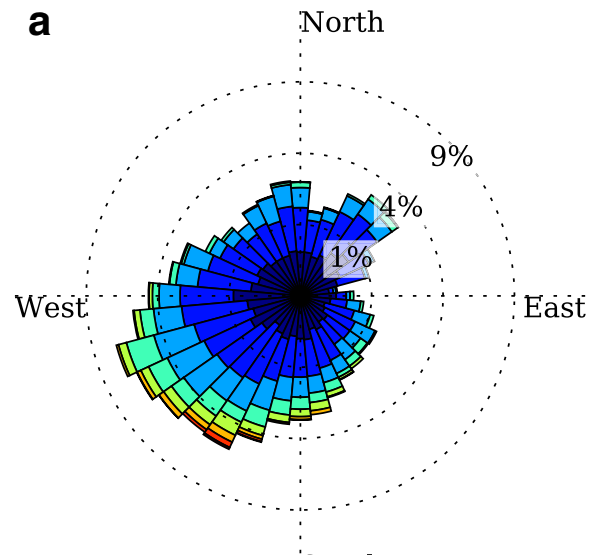

South
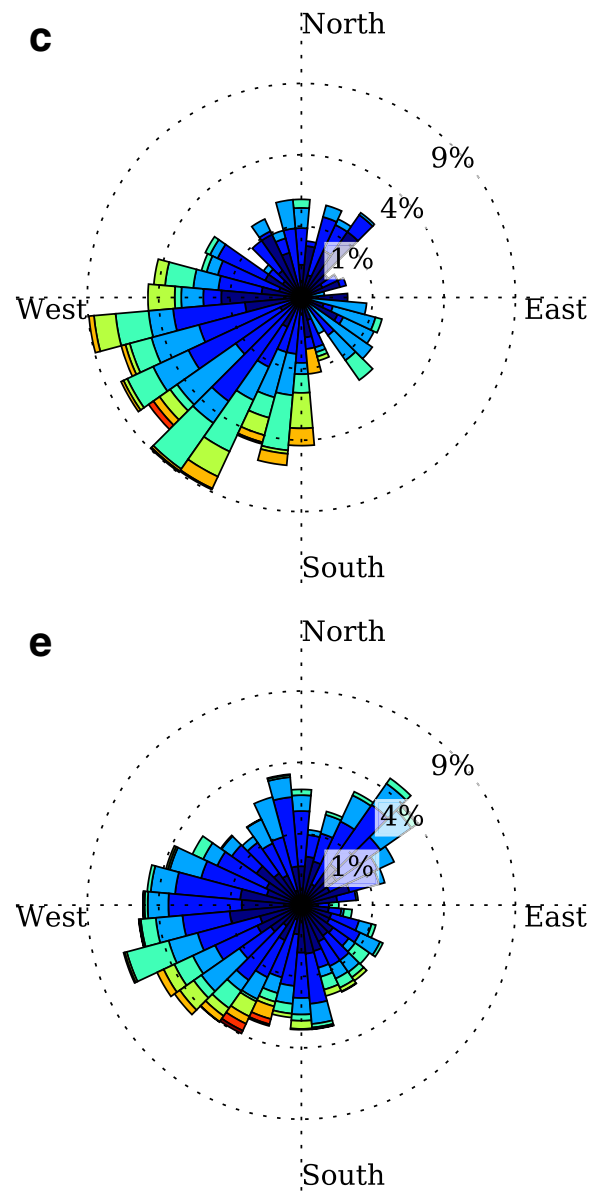
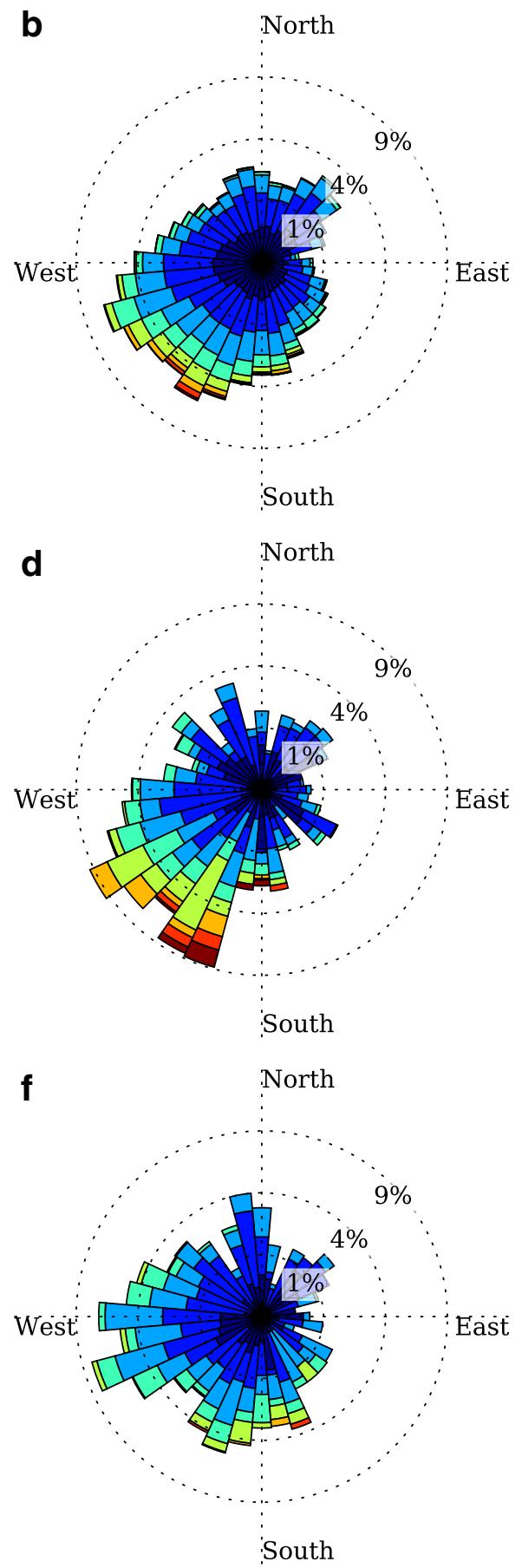

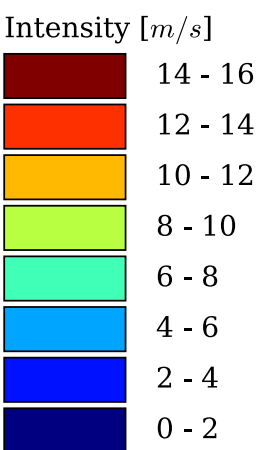

Fig. 8 The wind roses for the monitoring period $(\mathbf{a}, \mathbf{b})$, for the period with export during flood $(\mathbf{c}, \mathbf{d})$, and for the period with import during ebb $(\mathbf{e}, \mathbf{f})$ for the Kleine Noordwaard $(\mathbf{a}, \mathbf{c}, \mathbf{e})$ and Zuiderklip $(\mathbf{b}, \mathbf{d}, \mathbf{f})$ study areas

area to become negative during these strong SSW to SW wind events. The opposite effect occurs for strong $\mathrm{W}$ to $\mathrm{NW}$ wind: Fig. 8 e, b shows that it is mainly during these events that import during ebb takes place in the Zuiderklip area. This import arises because $\mathrm{W}$ to NW winds increase the flow in downstream/western direction. At the most upstream location ZK-SE, both the incoming discharge and SSC increase. Although the export of water at the downstream location ZK-W also increases, the SSC in the outflowing water are low at this location, which indicates that the sediment is effectively trapped in the area. The impact of these exceptions on the total sediment budget is however small. Sediment export was found for $7.7 \%$ of the total flood duration in the Kleine Noordwaard area, and for $12 \%$ of the 
flood duration in Zuiderklip, and it accounted for only 0.9 and $3 \%$, respectively, of the total export that took place during the monitoring periods. Import took place during $22.3 \%$ (Kleine Noordwaard) and $5.3 \%$ (zuiderklip) of the ebb period, but it explains only $5.4 \%$ (Kleine Noordwaard) and $1.6 \%$ (Zuiderklip) of the sediment import.

Figure 9 shows the distributions of hourly trapping efficiency for both the Kleine Noordwaard (a) and Zuiderklip
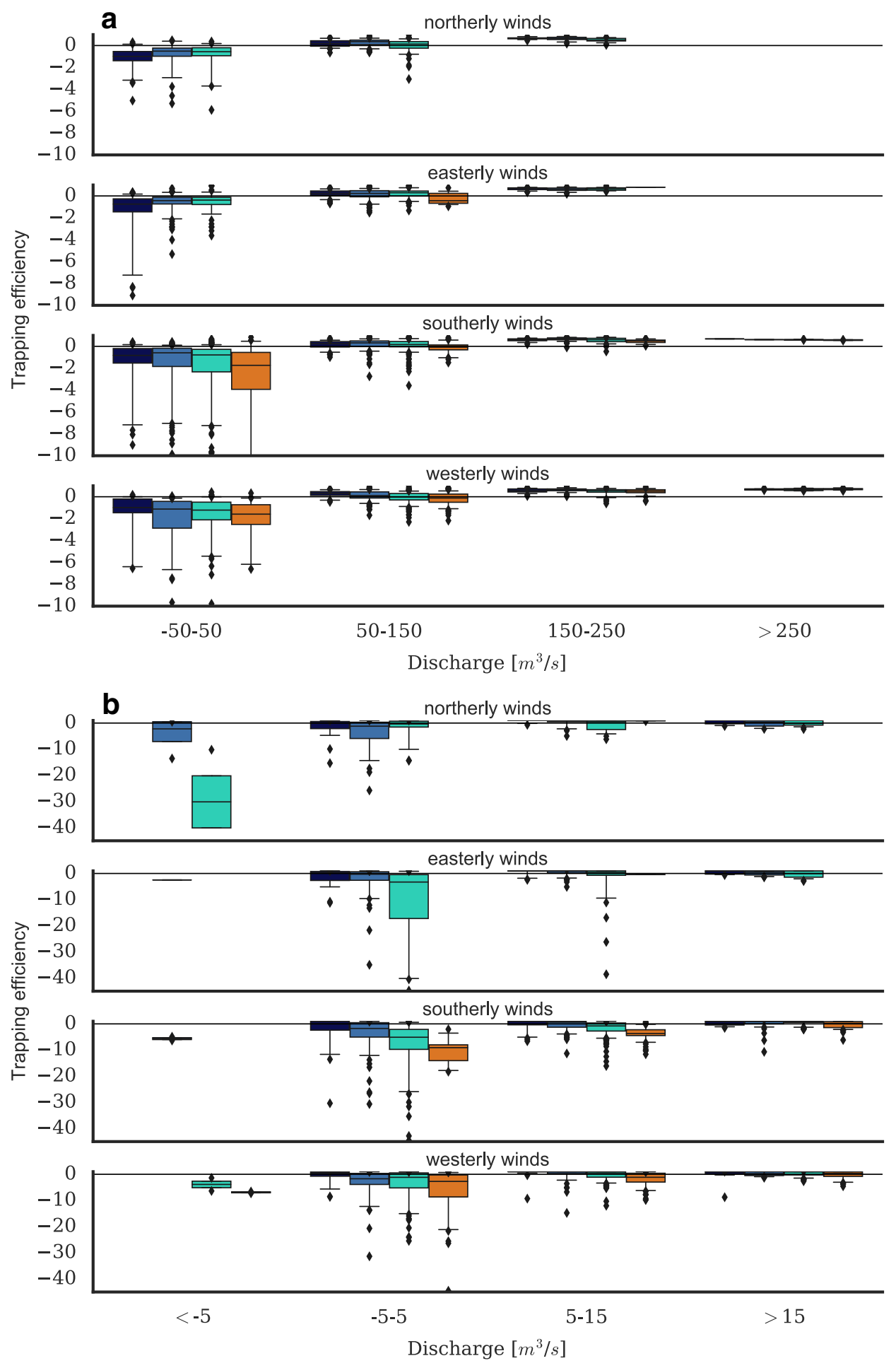

- Outlier

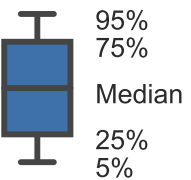

Intensity $[\mathrm{m} / \mathrm{s}]$

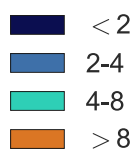

Fig. 9 The trapping efficiency for different classes of wind direction, wind strength (box-whisker plots) and incoming discharge (x-axis) at the main inlet of the study areas for both the Kleine Noordwaard (a) and Zuiderklip (b). Note the different scales of the axes for the two study areas 
(b) study area, with respect to different classes of wind direction, wind strength, and incoming discharge at the main inlet of the study areas. This figure shows the same pattern as shown in Fig. 6. Sediment trapping efficiencies are generally negative during negative or low discharges at the polder inlet and increase with river discharge. For the Kleine Noordwaard, the trapping efficiency becomes generally positive for incoming discharge greater than $150 \mathrm{~m}^{3} \mathrm{~s}^{-1}$. The Zuiderklip area generally starts to trap sediment at incoming discharges greater than about $5 \mathrm{~m}^{3} \mathrm{~s}^{-1}$.

In both study areas, the export of sediment during low discharges is greater during south and westerly winds. For the mid-range discharge classes, the trapping efficiency decreases with increasing wind strength. In the Kleine Noordwaard, this effect also occurs during south and westerly winds and discharges less than $50 \mathrm{~m}^{3} \mathrm{~s}^{-1}$. In contrast, it seems that less sediment is exported from this area for an increasing wind strength for north and easterly winds. Except for these situations, the trapping efficiency does not seem to be affected by wind strength at low discharges. The wind strength does also not affect the trapping efficiency at the highest discharges, except for westerly winds in the Zuiderklip area, where the trapping efficiency decreases due to a higher wind speed.

\section{Discussion}

In this study we presented the short term sediment budgets and trapping efficiencies of two tidal freshwater wetlands and how these budgets and efficiencies change under different hydro-meteorological boundary conditions.

In the Kleine Noordwaard study area, the mean annual area-normalised sediment budget amounted to $4.8 \mathrm{~kg}$ $\mathrm{m}^{-2} \mathrm{y}^{-1}$, which corresponds to a net area averaged sediment accumulation rate of $4.2 \mathrm{~mm} \mathrm{y}^{-1}$. This rate is slightly less than, but in same order as the average net accumulation rate of $5.2 \mathrm{~mm} \mathrm{y}^{-1}$ over the entire period since depoldering of the area (Van der Deijl et al., 2017). The slightly lower value found in this study fits well to the observation that accumulation rates have decreased over time since the opening of the polder area (Van der Deijl et al., 2017).

For the Zuiderklip study area we measured a negative area-normalised sediment budget of $-0.28 \mathrm{~kg} \mathrm{~m}^{-2} \mathrm{y}^{-1}$. However, we expected a positive budget, since observations during the field campaigns indicated the presence of a thin, newly deposited mud layer in the area. Moreover, bathymetric maps provided by Rijkswaterstaat also indicate sediment accumulation in the channels in the Zuiderklip area between 2012 and 2015. A first explanation of the negative sediment budget calculated for the Zuiderklip area can be found in the somewhat weaker fits between SSC and STM turbidity (see Table S2 in Electronic Supplementary Material 1), which may increase the chance of bias in the SSC and sediment fluxes at the monitoring locations. To quantify the effect of the error in SSC measurements on the estimation of the sediment budget, the temporal autocorrelation function of the SSC measurement error should be known, which is not the case. Nevertheless, considering the length of the monitoring period, we assess that the effect of the measurement error is only small and the net sediment budget of Zuiderklip area is at least very close to zero. A second explanation for the negative sediment budget can be found in internal production of suspended matter due to algal growth or resuspension. The fact that the sediment export accelerated during fall (November 2015 - January 2016; see Fig. 5B), i.e. the period when algal growth is minimal, suggests that the suspended matter production by algae only plays a minor role and that the net sediment export can be mainly attributed to resuspension.

The net area averaged sediment accumulation rate in the Kleine Noordwaard is within the range of reported overbank sedimentation rates between 0.2 and $11.6 \mathrm{~mm} \mathrm{y}^{-1}$ for the upstream river floodplains along the River Waal (Middelkoop 1997). Low rates of accumulation of 0.6 to $1.2 \mathrm{~mm}$ year $^{-1}$ have among others been found by Craft and Casey (2000), while high rates of accumulation in the order of $20-180 \mathrm{~mm}_{\text {year }}{ }^{-1}$ have been found by Darke and Megonigal (2003), Mitsch et al. (2014), Auerbach et al. (2015), and Roberts et al. (2015). Negative sediment budgets, such as found for the Zuiderklip area, have been reported by among others (Sheehan and Ellison 2015) and Van der Wal and Pye (2004). All these areas have different boundary conditions controlling the sediment accumulation, but the sediment supply seems to be the most important factor, which is in line with our results. The average SSC of $15 \mathrm{mg} \mathrm{l}^{-1}$ as found in the Biesbosch area is very low compared to other river systems with higher rates of accumulation.

Apart from the differences in sediment budget, the sediment trapping efficiencies also differ remarkably between the study areas. The trapping efficiency amounted to 0.29 for the Kleine Noordwaard area, whereas it amounted to 0.12 for the Zuiderklip area. Low trapping efficiencies of $0.10-0.20$ have been reported by Syvitski et al. (2009) for small, steep-gradient rivers and efficiencies of $0.50-0.60$ for larger deltas with multiple distributary channels. Multiple studies on sediment retention have reported sediment trapping efficiencies between 0.27 and nearly 1.0 for Mississippi and Atchafalaya diversion systems (Xu et al. 2016), where the trapping efficiency was higher further from the coast (Roberts et al. 2015; Xu et al. 2016).

The theoretical maximum trapping efficiency based on the settling velocity of the sediment, the residence time of water in the area, the water depth and water discharge entering or leaving the area, assuming that the suspended 
sediment is well-mixed across the water depth, reads (Chen 1975 in Asselman and Van Wijngaarden 2002):

$E=1-\exp \left(-w_{s} \frac{A}{Q}\right)$

Where $w_{s}$ is the settling velocity of the suspended sediment particles $\left(\mathrm{m} \mathrm{s}^{-1}\right), A$ the average water surface area of the study areas $\left(\mathrm{m}^{2}\right)$, and $Q$ the average incoming discharge $\left(\mathrm{m}^{3} \mathrm{~s}^{-1}\right)$. The A/Q ratio corresponds to the ratio between the residence time and the water depth.

Assuming a settling velocity $\mathrm{w}_{s}$ of $0.04 \mathrm{~mm} \mathrm{~s}^{-1}$ as measured by Van der Deijl EC et al. (2015) on suspended sediment in water samples from the Kleine Noordwaard, the theoretical trapping efficiency amounts to 0.72 for the Kleine Noordwaard and 0.80 for the Zuiderklip. The smaller value for the Kleine Noordwaard is caused by a smaller A/Q ratio due to a higher average incoming discharge, a larger inundation depth at the tidal flats and a smaller water surface area.

The observed trapping efficiency for the Kleine Noordwaard, however, is considerably smaller than the theoretical value. This can be attributed to (1) flow or wind-induced turbulence which causes a reduction in the effective settling velocity or even resuspension of sediment and (2) reduced exchange between the channels and tidal flats which reduces the effective surface area where sediment trapping takes place. These factors play probably an even larger role in the Zuiderklip area. Here, different sediment characteristics may play an additional role. Because of its position further away from the feeding rivers, a relatively large fraction of the sediment of the River Meuse has already been lost before the river water enters the Zuiderklip area. This becomes manifested in the lower mean SSC at the main inlet of the Zuiderklip area compared to the mean SSC at the main inlet of the Kleine Noordwaard. This may cause that the coarser fraction of sediment that readily settles has already been removed from the water column as it enters the Zuiderklip area. Visual inspection of the filters after filtration and drying of the water samples, taken at the monitoring locations confirms that suspended sediment entering the Zuiderklip area is in general finer than the sediment entering the Kleine Noordwaard area. The finer remaining fraction that enters the Zuiderklip area has a lower effective settling velocity. Although the lower effective settling velocity and reduced exchange between the channels and tidal flats may considerably reduce the trapping efficiency, these factors cannot explain the negative trapping efficiency for the Zuiderklip area. The fact that the trapping efficiency is negative can only be explained by internal sediment production, which we mainly attribute to resuspension.

Resuspension or prevention of sediment settling is caused by increased flow or wind-induced shear stress. The effect of resuspension or prevention of sediment settling due to increased flow velocities became apparent in the reduced trapping efficiency at discharges greater than $3000 \mathrm{~m}^{3} \mathrm{~s}^{-1}$ and $700 \mathrm{~m}^{3} \mathrm{~s}^{-1}$ in the respective Kleine Noordwaard and Zuiderklip study areas. This is in line with the results of the study by Asselman and Middelkoop (1998), who also observed a decrease in trapping efficiency due to increased flow velocities and shear stresses. The effect of resuspension due to wind is illustrated by the observed enhanced sediment export during south and westerly winds at low discharges in both study areas. We also observed a decrease in trapping efficiencies with increasing wind strength for the mid-range river discharges. These findings confirm the findings by Davidson-Arnott et al. (2002), who stated that not only a large input of SSC (by large river discharges) is required for large amounts of sediment deposition but also a low wave activity. Van der Wal and Pye (2004), Möller (2006), Fagherazzi et al. (2007), Delgado et al. (2013), and Fagherazzi et al. (2013) showed that wind wave related shear stress is decreased by vegetation and topographic irregularities. In our study, this effect was reflected in a decrease in observed sediment export from the Kleine Noordwaard study area under conditions of moderately north and easterly winds at low river discharges, since the tidal flats in the north and east of the Kleine Noordwaard area are characterised by a relatively irregular topography due to vegetated remnants of old embankments and polder drainage ditches.

In general, sediment import occurs during flood and export during ebb. However, in the Kleine Noordwaard, net sediment export during ebb becomes increasingly overruled by the increased import of sediment during high river discharge. This latter effect is nearly absent in the Zuiderklip area, where the tidal effect is larger than in the Kleine Noordwaard. In the Kleine Noordwaard, the incoming and outgoing discharge due to tide (as calculated from the water surface area and average tidal range) is only $40 \%$ of the observed mean discharge, whereas in the Zuiderklip this tidal discharge is $63 \%$ of the observed mean discharge. If only this tidal in- and outflow is taken into account, the residence time of the water in both areas, and hence, the theoretical trapping efficiency (1) would increase. But, because the sediment import is proportional with discharge, the theoretical amount of sediment trapped under only tidal flow would decrease by $55 \%$ in the Kleine Noordwaard and by $27 \%$ in the Zuiderklip, when compared to the amount resulting from total discharge. This is in line with the low sediment accumulation rate of $1-2 \mathrm{~mm}_{\text {year }}{ }^{-1}$ measured in the Mariapolder, a re-opened polder area only subject to tidal in- and outflow, which is located north of the Nieuwe Merwede, close to the Kleine Noordwaard (Bleuten et al. 2009). Indeed, this rate is about 60-80 \% lower than the sediment accumulation rate we observed in the Kleine Noordwaard, which is dominated by river inflow. Still, it should be noted that the abovementioned decrease 
in sediment trapping assumes that the SSCs at the inlets do not change. Yet, the SSCs will likely decrease in the case of only tidal in- and outflow, because the lower discharge will also cause an increase in water residence time in the feeding channels and, consequently, an enhanced depletion of sediment before it reaches the areas. This would lead to an even further decrease in sediment accumulation in both re-opened polder areas.

Finally, the Zuiderklip area is situated at a larger distance from the feeding river than the Kleine Noordwaard. Along with the fact that the River Meuse, which feeds the Zuiderklip area, has a lower discharge than the River Rhine, which feeds the Kleine Noordwaard area. This might lead to situations that during a tidal cycle the water body within the feeding channels and Zuiderklip is not entirely replaced with new river water and sediment. Instead, a considerable part of this water may shift in upstream and downstream direction along with the tides, but remains within the area, and progressively loses its sediment within the feeding channels, resulting in low accumulation rates in the Zuiderklip.

Our findings provide support for the conceptual premise that the Kleine Noordwaard study area has more sediment accumulation and a higher trapping efficiency than the Zuiderklip study area, because of four reasons: (1) there is a larger and more constant supply of river water and suspended sediment to the Kleine Noordwaard area when compared to the Zuiderklip area; (2) the water at the inlet of the Zuiderklip area contains only the finer sediment fraction that takes not only more time, but also requires more quiescent conditions to settle out than the sediment that enters the Kleine Noordwaard; (3) the exchange of water and sediment between the channels and tidal flats is more intense in the Kleine Noordwaard due to a larger inundation depth at the tidal flats and the constant river supply; and (4) the impact of wind and tide is less prominent in the Kleine Noordwaard area, because of the larger inundation depth at the bare tidal flats, the presence of often vegetated topographic irregularities, wider and deeper channels, and larger water flow velocities due to the constant river supply.

The net area averaged sediment accumulation rate of $4.2 \mathrm{~mm} \mathrm{year}^{-1}$ in the Kleine Noordwaard study area is just enough to compensate the actual rate of sea-level rise and soil subsidence in the Netherlands, which are $2 \mathrm{~mm}_{\text {year }}{ }^{-1}$ (Ligvoet et al. 2015) and 0.5-2.5 mm year ${ }^{-1}$ for the Biesbosch (Kooi et al. 1998). However, the accumulation can not compensate the high end scenarios for sea-level rise in the Netherlands of 0.4 to $10.5 \mathrm{~mm} \mathrm{y}^{-1}$ (Katsman et al. 2011), especially since freshly deposited sediment will compact over the years and thus result in a lower net accumulation. However, we conclude that sediment fluxes for longer periods may be underestimated, since events with high discharge and suspended sediment concentrations with return periods considerably greater than the monitoring period are missing in the observed time series. Furthermore, the role of vegetation in increased sedimentation of suspended material and accretion due to production of organic material as found by Darke and Megonigal (2003), Day et al. (2011), Schile et al. (2014) and (DeLaune et al. 2016) is negligible in both the Kleine Noordwaard and Zuiderklip areas.

\section{Conclusions}

The present study was designed to identify the factors, controlling the sediment trapping of freshwater tidal wetlands. We used two recently re-opened polder areas in the Biesbosch, The Netherlands, as study area, taking the advantage of the differences in geographical setting and boundary conditions of the two nearby wetland areas that are similar in climate conditions and tidal range. The main conclusions of this study are:

1. The net sediment accumulation rate in a wetland increases for higher upstream river discharge due to the associated higher water inflow and suspended sediment concentration at the main inlets of the study areas. However, a relatively large fraction of the sediment of the River Meuse is already lost before the river water enters the Zuiderklip study area.

2. Although sediment trapping increases with increasing upstream river discharge, the trapping efficiency does not increase at high river discharge due to a decrease in residence time and an increase in shear stress preventing sediment particles to settle.

3. Sediment is in general imported during flood and exported during ebb, but the export during ebb can be overruled by the increased upstream import of sediment during high river discharges.

4. The sediment trapping efficiency decreases with increasing wind strength for mid-range river discharges because wind waves and associated increased shear stress hampers sediment settling or even causes resuspension.

Therefore, it can be concluded that the supply of sediment is the major factor controlling the sediment budget of a wetland. This not only controlled by the sediment load in the main feeding river, but also by the proximity of the wetland to the main feeding river. The next major factor is wind which determines the trapping efficiency.

These findings of this study have a number of important implications for future practice of river delta restoration. An important practical implication is that delta restoration through the creation of new wetlands, in which sedimentation compensates for sea-level rise and soil subsidence, could only be effective when there is a sufficient supply of water and sediment to the newly created wetland. 
Delta restoration should therefore aim at optimising the conveyance of sediment from the river or tidal channels to the wetland. Once the sediment supply is optimised, wetland management should focus on enhancing the trapping efficiency of the incoming sediment.

Acknowledgements This project is financed by the Dutch Technology Foundation STW (project nr. 12431). We thank Staatsbosbeheer Rijkswaterstaat, Deltares, and Dr. Hans de Boois for the provided data, assistance, logistic support, and knowledge.

Open Access This article is distributed under the terms of the Creative Commons Attribution 4.0 International License (http:// creativecommons.org/licenses/by/4.0/), which permits unrestricted use, distribution, and reproduction in any medium, provided you give appropriate credit to the original author(s) and the source, provide a link to the Creative Commons license, and indicate if changes were made.

\section{References}

Anderson CJ, Mitsch WJ (2007) Erratum to: Sediment, carbon, and nutrient accumulations at two 10-year-old created riverine marshes. Wetlands 27(3):774-774

Asselman NEM, Middelkoop H (1998) Temporal variability of contemporary floodplain sedimentation in the Rhine-Meuse Delta, the Netherlands. Earth Surf Proc Land 23:595-609

Asselman NEM, Van Wijngaarden M (2002) Development and application of a 1D floodplain sedimentation model for the River Rhine in the Netherlands. J Hydrol 268(1-4):127-142

Auerbach LW, Goodbred Jr SL, Mondal DR, Wilson CA, Ahmed KR, Roy K, Steckler MS, Small C, Gilligan JM, Ackerly BA (2015) Flood risk of natural and embanked landscapes on the GangesBrahmaputra tidal delta plain. Nat Clim Chang 5(2):153-157

Bleuten W, Borren W, Kleinveld E, Oomes LB, Timmermann T (2009) Water and nutrient balances of the experimental site Mariapolder, The Netherlands. In: Barendrecht A, Whigham DF, Baldwin AH (eds) Tidal FreshwWetl. Backhuys Publishers, Leiden, pp 167-206. chap 18

Calvo-Cubero J, Ibáñez C, Rovira A, Sharpe PJ, Reyes E (2013) Mineral versus organic contribution to vertical accretion and elevation change in restored marshes (Ebro Delta, Spain). Ecol Eng 61:12-22

Craft CB, Casey WP (2000) Sediment and nutrient accumulation in floodplain and depressional freshwater wetlands of Georgia, USA. Wetlands 20(2):323-332

Darke AK, Megonigal JP (2003) Control of sediment deposition rates in two mid-Atlantic Coast tidal freshwater wetlands. Estuar Coast Shelf Sci 57(1-2):255-268

Davidson-Arnott RG, Van Proosdij D, Ollerhead J, Schostak L (2002) Hydrodynamics and sedimentation in salt marshes: examples from a macrotidal marsh, Bay of Fundy. Geomorphology 48(1-3):209231

Day JW, Boesch DF, Clairain EJ, Kemp GP, Laska SB, Mitsch WJ, Orth K, Mashriqui H, Reed DJ, Shabman L, Simenstad CA, Streever BJ, Twilley RR, Watson CC, Wells JT, Whigham DF (2007) Restoration of the Mississippi Delta: Lessons from Hurricanes Katrina and Rita. Science 315(5819):1679-1684

Day JW, Kemp GP, Reed DJ, Cahoon DR, Boumans RM, Suhayda JM, Gambrell R (2011) Vegetation death and rapid loss of surface elevation in two contrasting Mississippi delta salt marshes: The role of sedimentation, autocompaction and sea-level rise. Ecol Eng 37(2):229-240
Day JW, Agboola J, Chen Z, D'Elia C, Forbes DL, Giosan L, Kemp P, Kuenzer C, Lane RR, Ramachandran R, Syvitski J, YañezArancibia A (2016) Approaches to defining deltaic sustainability in the 21st century. Estuar Coast Shelf Sci 183:275-291

De Bont C, Dirkx G, Maas G, Wolfert H, Odé O, Polman G (2000) Aardkundige en cultuurhistorische landschappen van de Biesbosch; Beschrijving en waardering als bouwstenen voor het landschapsontwikkelingsconcept en de effectevaluatie voor rivierverruiming. Technical report, Alterra, Research Instituut voor de Groene Ruimte, Wageningen, DOI RIZA-rapport 2000.053, http://edepot.wur.nl/119881

De la Haye MAA (2011) Jaarrapportage 2010 projectgebonden monitoring RWS Zuid-Holland, Noordwaard, Sliedrechtse Biesbosch, Oeverlanden Hollandsch Diep (APL-polder) en Het Gors en De Aanwas. Technical report, Grontmij

De la Haye MAA (2012) Jaarrapportage 2011 projectgebonden monitoring RWS Zuid-Holland. Saneringen: Moordrecht-Oost, Groenendijk, Spuisluis, Parkslik en Begraafplaats in de Hollandsche IJssel. Natuurontwikkelingen: Zuiderklip, 3 Spuigorzen, Oeverlanden Hollandsch Diep, Het Gors. Technical report, Grontmij

DeLaune R, Sasser C, Evers-Hebert E, White J, Roberts H (2016) Influence of the Wax Lake Delta sediment diversion on aboveground plant productivity and carbon storage in deltaic island and mainland coastal marshes. Estuar Coast Shelf Sci 177:83-89

DeLaune RD, Jugsujinda A, Peterson GW, Patrick WH (2003) Impact of Mississippi River freshwater reintroduction on enhancing marsh accretionary processes in a Louisiana estuary. Estuar Coast Shelf Sci 58(3):653-662

Delgado P, Hensel PF, Swarth CW, Ceroni M, Boumans R (2013) Sustainability of a tidal freshwater marshexposed to a long-term hydrologic barrier and sea level rise. Estuar Coast 36(3):585594

Fagherazzi S, Palermo C, Rulli MC, Carniello L, Defina A (2007) Wind waves in shallow microtidal basins and the dynamic equilibrium of tidal flats. J Geophys Res 112:12

Fagherazzi S, Wiberg PL, Temmerman S, Struyf E, Zhao Y, Raymond PA (2013) Fluxes of water, sediments, and biogeochemical compounds in salt marshes. Ecol Process 2(1):3

French JR, Spencer T (1993) Dynamics of sedimentation in a tidedominated backbarrier salt marsh, Norfolk, UK. Mar Geol 110(34):315-331

Giosan L, Constantinescu S, Filip F, Deng B (2013) Maintenance of large deltas through channelization: Nature vs. humans in the Danube delta. Anthropocene 1:35-45

Giosan L, Syvitski J, Constantinescu S, Day J (2014) Climate change: Protect the world's deltas. Nature 516(7529):31-33

Hudson PF, Middelkoop H, Stouthamer E (2008) Flood management along the Lower Mississippi and Rhine Rivers (The Netherlands) and the continuum of geomorphic adjustment. Geomorphology 101(1-2):209-236

Ibáñez C, Canicio A, Day JW, Curco A (1997) Morphologic development, relative sea level rise and sustainable management of water and sediment in the Ebro Delta, Spain. J Coast Consv 3(2):191-202

Ibáñez C, Day JW, Reyes E (2014) The response of deltas to sealevel rise: Natural mechanisms and management options to adapt to high-end scenarios. Ecol Eng 65:122-130

Katsman CA, Sterl A, Beersma JJ, Van den Brink HW, Church JA, Hazeleger W, Kopp RE, Kroon D, Kwadijk J, Lammersen R, Lowe J, Oppenheimer M, Plag HP, Ridley J, Von Storch H, Vaughan DG, Vellinga P, Vermeersen LLA, van de Wal RSW, Weisse R (2011) Exploring high-end scenarios for local sea level rise to develop flood protection strategies for a low-lying delta-the Netherlands as an example. Clim Chang 109(3-4):617-645

Khadim FK, Kar KK, Halder PK, Rahman MA, Morshed AM (2013) Integrated Water Resources Management (IWRM) impacts 
in south west coastal zone of Bangladesh and fact-finding on Tidal River Management (TRM). J Water Resour Prot 05 (10):953-961

Kirwan ML, Megonigal JP (2013) Tidal wetland stability in the face of human impacts and sea-level rise. Nature 504(7478):53-60

Kleinhans MG, Weerts HJ, Cohen KM (2010) Avulsion in action: Reconstruction and modelling sedimentation pace and upstream flood water levels following a Medieval tidal-river diversion catastrophe (Biesbosch, The Netherlands, 1421-1750AD). Geomorphology 118(1-2):65-79

KNMI (2016) Uurgegevens van het weer in Nederland. http://projects. knmi.nl/klimatologie/uurgegevens/selectie.cgi

Kooi H, Johnston P, Lambeck K, Smither C (1998) Geological causes of recent $(100 \mathrm{yr})$ vertical land movement in the Netherlands. Tectonophysics 299(4):297-316

Ligvoet W, Bregman B, Dorland R, Ten Brinke W, De Vos R, Petersen A, Visser H (2015) Klimaatverandering. Samenvatting van het vijfde IPCC-assessment en een vertaling naar Nederland. http://www.stowa.nl/Upload/nieuws/Klimaatverandering Samenvatting van het vijfde IPCC-assessment en een vertaling naar Nederland.pdf

Middelkoop H (1997) Embanked floodplains in the Netherlands. Geomorphological evolution over various time scales. Phd thesis, Utrecht University, The Netherlands. Geographical Studies 224

Middelkoop H, van der Perk M (1998) Modelling spatial patterns of overbank sedimentation on embanked floodplains. Geogr Ann 80A:95-109

Mitsch WJ, Nedrich SM, Harter SK, Anderson C, Nahlik AM, Bernal B (2014) Sedimentation in created freshwater riverine wetlands: 15 years of succession and contrast of methods. Ecol Eng 72:25-34

Möller I (2006) Quantifying saltmarsh vegetation and its effect on wave height dissipation: Results from a UK East coast saltmarsh. Estuar Coast Shelf Sci 69(3):337-351

Morse JL, Megonigal JP, Walbridge MR (2004) Sediment nutrient accumulation and nutrient availability in two tidal freshwater marshes along the Mattaponi River, Virginia, USA. Biogeochem 69(2):175-206

Noe GB, Hupp CR, Bernhardt CE, Krauss KW (2016) Contemporary deposition and long-term accumulation of sediment and nutrients by tidal freshwater forested wetlands impacted by sea level rise. Estuar Coast 39(4):1006-1019

Noord-Brabant DLG (2009) MER Zuiderklip Hoofdrapport. Technical report, Royal Haskoning B.V

Noordwaard B (2006) Ontwerpvisie ontpoldering noordwaard. Technical report, Rotterdam

Orson RA, Simpson RL, Good RE (1990) Rates of sediment accumulation in a tidal freshwater marsh. J Sediment Res 60(6):

Paola C, Twilley RR, Edmonds DA, Kim W, Mohrig D, Parker G, Viparelli E, Voller VR (2011) Natural processes in delta restoration: application to the Mississippi Delta. Annu Rev Mar Sci 3:67-91

Reddy KR, DeLaune RD (2008) Biogeochemistry of wetlands : science and applications. CRC Press

Reed DJ (1992) Effect of weirs on sediment deposition in Louisiana coastal marshes. Environ Manage 16(1):55-65

Reed DJ, De Luca N, Foote aL (1997) Effect of hydrologic management on marsh surface sediment deposition in coastal Louisiana. Estuaries 20(2):301

Reed DJ, Spencer T, Murray AL, French JR, Leonard L (1999) Marsh surface sediment deposition and the role of tidal creeks: Implications for created and managed coastal marshes. J Coast Consv 5:81-90

Rijkswaterstaat (2011) Water Management in the Netherlands. Technical report, Ministry of Infrastructure and Environment, Directorate-General Water and Rijkswaterstaat, Centre for Water
Management, https://staticresources.rijkswaterstaat.nl/binaries/ WaterManagementintheNetherlands_tcm21-37646.pdf

Rijkswaterstaat (2016) Water data. https://www.watergegevens.rws.nl/ Rijkswaterstaat Ruimte voor de Rivier (2016) Ruimte voor de Rivier. https://www.ruimtevoorderivier.nl/

Roberts HH, DeLaune RD, White JR, Li C, Sasser CE, Braud D, Weeks E, Khalil S (2015) Floods and cold front passages: Impacts on coastal marshes in a river diversion setting (Wax Lake delta area, Louisiana). J Coast Res 315:1057-1068. http://www.bioone. org/doi/10.2112/JCOASTRES-D-14-00173.1

Schile LM, Callaway JC, Morris JT, Stralberg D, Thomas Parker V, Kelly M (2014) Modeling tidal marsh distribution with sealevel rise: Evaluating the role of vegetation, sediment, and upland habitat in marsh resiliency. PLoS One 9(2):

Schuerch M, Vafeidis A, Slawig T, Temmerman S (2013) Modeling the influence of changing storm patterns on the ability of a salt marsh to keep pace with sea level rise. J Geophys Res: Earth Surf 118(1):84-96

Sheehan MR, Ellison JC (2015) Tidal marsh erosion and accretion trends following invasive species removal, Tamar Estuary, Tasmania. Estuar Coast Shelf Sci 164:46-55. doi:10.1016/j.ecss.2015. 06.013. http://www.sciencedirect.com/science/article/pii/S027277 141500222X

Siobhan Fennessy M, Brueske CC, Mitsch WJ (1994) Sediment deposition patterns in restored freshwater wetlands using sediment traps. Ecol Eng 3(4):409-428

Syvitski JPM (2008) Deltas at risk. Sustain Sci 3(1):23-32

Syvitski JPM, Saito Y (2007) Morphodynamics of deltas under the influence of humans. Glob Planet Chang 57(3-4):261-282

Syvitski JPM, Kettner AJ, Overeem I, Hutton EWH, Hannon MT, Brakenridge GR, Day J, Vörösmarty C, Saito Y, Giosan L, Nicholls RJ (2009) Sinking deltas due to human activities. Nat Geosci 2(10):681-686

Temmerman S, Govers G, Wartel S, Meire P (2003) Spatial and temporal factors controlling short-term sedimentation in a salt and freshwater tidal marsh, scheldt estuary, Belgium, SW Netherlands. Earth Surf Proc Land 28(7):739-755

Temmerman S, Bouma TJ, Govers G, Wang ZB, De Vries MB, Herman PMJ (2005) Impact of vegetation on flow routing and sedimentation patterns: Three-dimensional modeling for a tidal marsh. J Geophys Res 110(F04019):1-18

Thonon I, Middelkoop H, Perk MVD (2007) The influence of floodplain morphology and river works on spatial patterns of overbank deposition. Neth J Geosci 81(1):63-75

Van der Deijl EC, Van der Perk M, Visser R, Verschelling E, Middelkoop $H$ (2015) Measurement of sediment settling velocities in a tidal freshwater wetland. In: Geophys Res Abstracts 17, EGU2015-7519

Vandenbruwaene W, Bouma TJ, Meire P, Temmerman S (2013) Bio-geomorphic effects on tidal channel evolution: impact of vegetation establishment and tidal prism change. Earth Surf Proc Land 38(2):122-132

Van der Wal D, Pye K (2004) Patterns, rates and possible causes of saltmarsh erosion in the Greater Thames area (UK). Geomorphology 61(3):373-391

van der Deijl EC, van der Perk M, Middelkoop H (2017) Establishing a sediment budget in the newly created "Kleine Noordwaard" wetland area in the Rhine-Meuse delta. Earth Surface Dynamics Discussions 2017(3):1-23. http://www.earth-surf-dynam-discuss.net/esurf-2017-22/. doi:10.5194/esurf-2017-22

Xu K, Bentley S, Robichaux P, Sha X, Yang H (2016) Implications of texture and erodibility for sediment retention in receiving basins of coastal Louisiana diversions. Water $8(1): 26$ 